\section{Let's Prefer the Pain Reducing Intervention, Buzzy or ShotBlocker: A Randomized Controlled Trial}

\author{
Ağrıyı Azaltan Girişimi Tercih Edelim, Buzzy veya \\ ShotBlocker: Bir Randomize Kontrollü Araştırma
}

\begin{abstract}
Objective: The aim of this study was to detect and compare the effects of ShotBlocker and Buzzy methods on pain, fear, and parental satisfaction during intramuscular injection.

Method: This study was an experimental randomized controlled trial. The sample included 90 children at the ages of 6 and 12 who applied to the pediatric emergency department of a university hospital and received intramuscular injections. The participants were randomly assigned to ShotBlocker $(n=30)$, Buzzy $(n=30)$, and control $(n=30)$ groups. Child Information Form, Wong-Baker FACES Pain Rating Scale, Children's Fear Scale, and Parental Satisfaction Questionnaire were used to collect the data.

Results: ShotBlocker and Buzzy groups had significantly lower pain and fear and higher parental satisfaction scores than the control group following injections ( $p=0.0001)$. The lowest pain and fear scores and the highest parental satisfaction scores were observed in the Buzzy group $(p=0.0001)$.

Conclusions: Both ShotBlocker and Buzzy methods are effective in reducing pain and fear of children during intramuscular injections and increasing satisfaction of their parents. However, when compared to the ShotBlocker method, Buzzy method is more effective in reducing intramuscular injection-related pain and fear and should be preferred primarily.
\end{abstract}

Keywords: Buzzy, children, intramuscular injection, pain, satisfaction

Öz

Amaç: Bu araștırmanın amacı, intramüsküler enjeksiyon sırasında uygulanan ShotBlocker ve Buzzy girişimlerinin çocuklarda ağrı, korku ve ebeveyn memnuniyeti üzerindeki etkisini belirlemek ve karşılaştırmaktır. Yöntem: Bu araştırma, randomize kontrollü deneysel bir çalışmadır. Araştırmanın örneklemini bir üniversite hastanesinin çocuk acil servisine başvuran ve intramüsküler enjeksiyon uygulanan 6-12 yaşları arasında 90 çocuk oluşturmuştur. Katııımcılar rastgele Buzzy $(n=30)$, ShotBlocker $(n=30)$ ve Kontrol $(n=30)$ gruplarına atanmıştır. Verilerin toplanmasında Çocuk Bilgi Formu, Wong Baker Ağrı Ölçeği, Çocuk Korku Ölçeği ve Ebeveyn Memnuniyet Anketi kullanılmıştır.

Bulgular: ShotBlocker ve Buzzy gruplarında enjeksiyon sonrası ağrı ve korku puanı ve ebeveyn memnuniyeti kontrol grubuna göre anlamlı derecede düşük bulundu ( $p=0.0001)$. En düşük ağrı ve korku puanı ile en yüksek ebeveyn memnuniyeti Buzzy grubunda gözlendi ( $p=0.0001)$.

Sonuç: ShotBlocker ve Buzzy yöntemleri, intramüsküler enjeksiyon sırasında çocuklarda ağrı ve korkunun azaltılmasında ve ebeveyn memnuniyetinin arttırılmasında etkilidir. Bununla birlikte, ShotBlocker ile karşılaştırıldığında, Buzzy yöntemi intramüsküler enjeksiyonla ilişkili ağrı ve korkuyu azaltmada daha etkilidir ve öncelikle tercih edilmelidir.

Anahtar kelimeler: Buzzy, çocuklar, intramüsküler enjeksiyon, ağrı, memnuniyet
Received/Geliş: 07.04.2020

Accepted/Kabul: 05.06.2020

Published Online: 22.12 .2020

Burcu Aykanat Girgin Sağılık Bilimleri Üniversitesi, Hamidiye Hemşirelik Fakültesi, İstanbul - Türkiye aykanat_87@hotmail.com ORCID: 0000-0002-2601-8781

E. Aktaş 0000-0003-1424-9678 Sağlık Bilimleri Üniversitesi, Hamidiye Hemşirelik Fakültesi, istanbul, Türkiye

D. Kılınç 0000-0002-2631-9138 Istanbul Zeynep Kamil Kadın ve Çocuk Hastalıkları Eğitim ve Araştırma

Hastanesi, Çocuk Acil Servisi, Istanbul, Türkiye

D. Gözen 0000-0001-9272-3561 istanbul Üniversitesi-Cerrahpaşa Florence Nightingale Hemşirelik Fakültesi, istanbul, Türkiye 


\section{INTRODUCTION}

Invasive interventions such as venous blood sampling, establishing vascular access, vaccinations, and intramuscular injections are among medical interventions causing pain and fear in childhood ${ }^{(1-3)}$. Thus, nurses should use methods for effective coping with pain in patients in order to prevent physical and emotional effects of pain during invasive procedures ${ }^{(4)}$.

ShotBlocker and Buzzy are two nonpharmacological methods used during painful interventions. Based on the gate control theory, pain symptoms caused by injection are blocked temporarily and the gates allowing pain symptoms through the central nervous system are closed during the use of these methods ${ }^{(5)}$.

ShotBlocker is a flat, noninvasive, horseshoeshaped and drug-free device, which is applied to relieve pain during intramuscular injections. It provides contact with the skin, has short and blunt points and an opening exposing the injection site in the middle of the tool ${ }^{(6)}$. The use of ShotBlocker is effective on reducing pain and fear during intramuscular injections ${ }^{(6-8)}$.

Buzzy (MMJ Labs, Atlanta, GA, USA) is a noninvasive tool in sizes of $8 \times 5 \times 2,5 \mathrm{~cm}$ used for reducing pain in children and adults during invasive procedures. The tool, which is placed $5 \mathrm{~cm}$ above the injection site 30-60 seconds before the invasive procedure, is fully contacted with the skin and radiates cold application and vibration during the procedure. The ice pack kept in the deep freezer is attached to the tool for the injection. Vibration and cold application are started right before the intramuscular injection and continued until the end of the procedure ${ }^{(9)}$. Buzzy application which uses vibration and cold application in combination is effective on relieving pain experienced by children during venous blood sampling ${ }^{(1,9-}$ ${ }^{11)}$, insertion of intravenous catheter ${ }^{(12,13)}$, vaccination ${ }^{(3,14)}$, and subcutaneous interventions ${ }^{(15)}$.

Painful interventions cause anxiety in both children and parents ${ }^{(2)}$ and the parent's anxiety during invasive procedure increases the child's procedural fear and pain ${ }^{(16)}$. Thus, parental satisfaction is thought to be effective on reducing the child's level of procedural pain and fear and nurses should plan interventions for parental satisfaction during invasive procedures, as well.

Antibiotic treatment is applied in children diagnosed with upper and lower respiratory tract infections due to bacterial reasons. Oral, intravenous, and intramuscular methods are used in antibiotic treatment of children ${ }^{(17)}$. Intravenous or intramuscular injection of antibiotics containing ceftriaxone as active substance is administered for the treatment of respiratory tract infections ${ }^{(18)}$. Just like intravenous interventions, intramuscular interventions cause pain and fear among children ${ }^{(4,14)}$. Most of the related studies have separately investigated the impacts of Buzzy and ShotBlocker methods on pain and fear of children during intramuscular, intravenous, and subcutaneous injections $(1,3,7,15)$. The difference of this study from similar studies in the literature is that this study examines the effect of both methods on pain and fear experienced by children and parental satisfaction. Differently from other studies, the effect of both interventions on pain, fear, and parental satisfaction was also investigated in the present study to determine the most effective intervention.

The following hypotheses were determined for the present study.

Hypothesis 1. ShotBlocker is effective in reducing pain of children and increasing parental satisfaction during intramuscular injection.

Hypothesis 2. Buzzy is effective in reducing pain of children and increasing parental satisfaction during intramuscular injection.

Hypothesis 3. Buzzy is more effective than ShotBlocker in reducing pain of children and increasing parental satisfaction during intramuscular injection.

\section{MATERIAL and METHODS}

\section{Design}

This randomized controlled and experimental trial was carried out in order to compare the effect of Buzzy and ShotBlocker methods on reducing pain and fear experienced by children during intramuscular injections and their parents' satisfaction. 


\section{Participants}

The study sample included 90 children who were 6 and 12 years old with a diagnosis of upper and lower tract respiratory infections and received intramuscular injections of ceftriaxone between November 2018 and May 2019 in the pediatric emergency department of a university hospital located in the Metropolitan City of Istanbul.

The inclusion criteria for the children were as follows: age range: 6-12 years; requirement of intramuscular injection of ceftriaxone for upper and lower respiratory tract infections; having cognitive ability to assess pain and fear scales, and agreeing to participate in the study. Patients receiving analgesics within the last 6 hours, and those with impaired skin integrity at the injection site were excluded from the study.

Sample size was calculated via Gpower 3.1 software. For 90 children, the power was $1-\beta=0.84$ with $\alpha=.05$ and effect size $(w)=.31^{(19)}$. Furthermore, the pre- and post-procedure pain and fear scores of the children were assessed by the children ( $n: 90)$, their parents $(n: 90)$, and the researcher who was speciali- zed in pediatric nursing $(n: 1)$ so that bias was prevented and the validity of the data was increased.

\section{Randomization}

The first researcher (author) assigned the children meeting the inclusion criteria to three groups (ShotBlocker, Buzzy and control groups). The children were stratified based on their gender and included in three groups via block randomization method (20). The girls and boys were randomly assigned to the related group by drawing lots from respectively pink and blue cloth bags prepared based on gender. The bags contained the papers with the same color and folding style for the three groups. Necessary explanations were made for the parents and the children to achieve a randomized distribution. By this way, the groups became automatically balanced. After making a gender match for intervention and control groups within themselves, totally 30 children ( 15 girls and 15 boys) were assigned to each group. In the study, the CONSORT guideline was followed. Figure 1 demonstrates the flow diagram of the children.

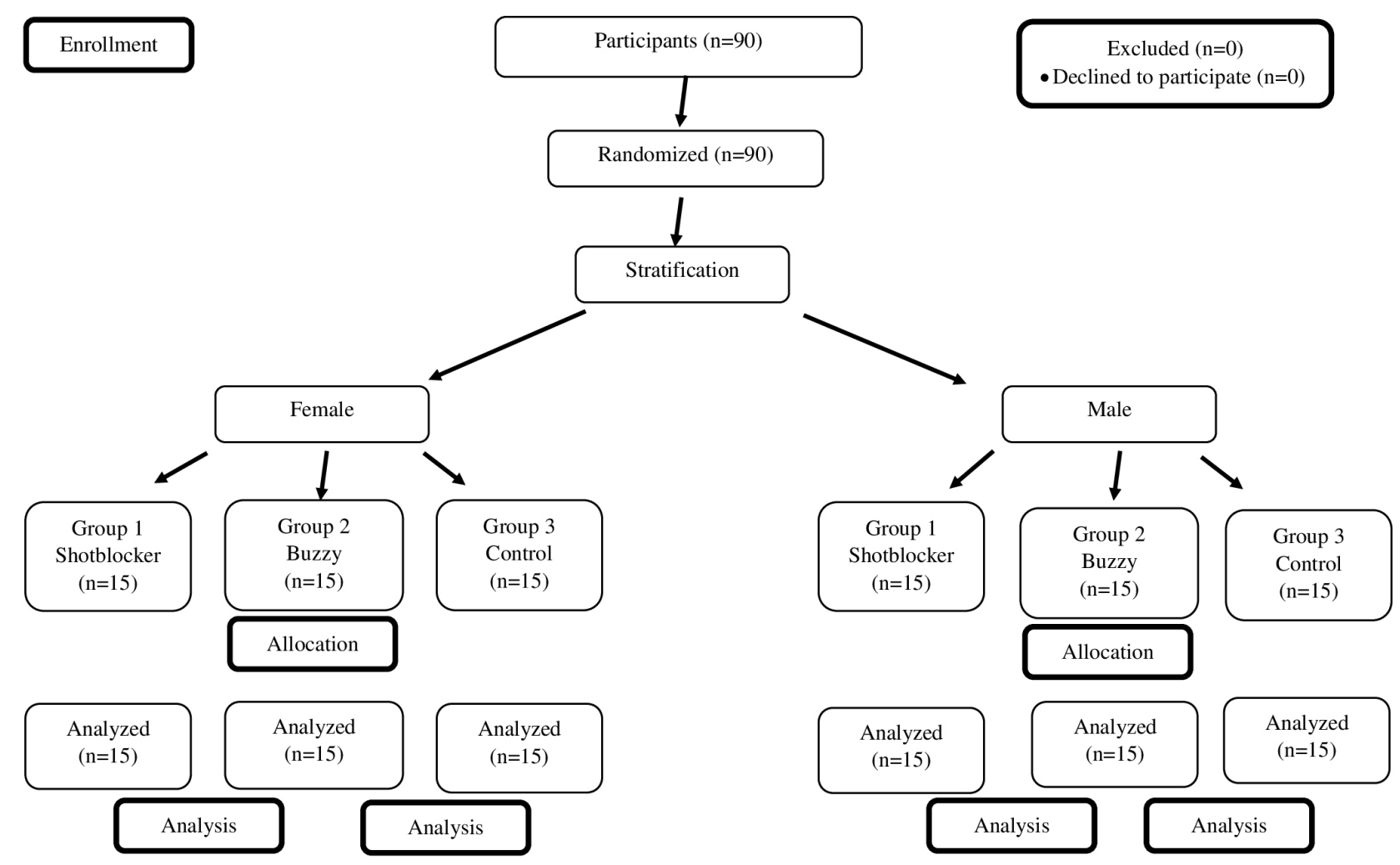

Figure 1. Flow diagram of participants. 


\section{Measurements}

The data were collected using data collection forms as follows.

\section{Child Information Form}

The form consists of totally five questions about the child's age, gender, weight, number of intramuscular injections applied within one year, and the state of applying an intervention before for reducing pain experienced during intramuscular injection.

\section{The Wong-Baker Faces Pain Rating Scale}

The scale was developed in 1981 for assessing the pain intensity of 3-18 year-old children and revised

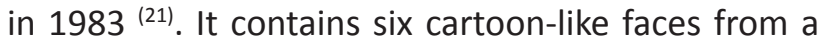
smiling face ( $0=$ very happy/no pain) to a crying face (10=worst pain). The scale is a valid and reliable assessment tool which is commonly used in pain assesment studies ${ }^{(22)}$.

\section{Children's Fear Scale}

The scale is a valid and reliable measurement tool developed in 2011 to evaluate the fear level of children. It includes five facial expressions and the fear score is obtained by giving numerical values to the facial expressions. The face on the left edge indicates no fear ( 0 point); whereas, the face on the right edge indicates too much fear (4 points) ${ }^{(2)}$.

\section{Parental Satisfaction Questionnaire}

The questionnaire was used for evaluating parental satisfaction concerning intramuscular injection. The questionnaire consists of five questions evaluated with the options yes and no regarding the parent's satisfaction with pre-procedure explanation and preparation by the nurse, child's comfort during injection, satisfaction with the method of injection and use, and recommendation of the same method in the following periods.

\section{Interventions}

The first researcher (author) assessed all children and parents to check their compliance with the inclusion criteria. Those meeting the inclusion criteria were informed about the purpose of the study. Their verbal and written consents were obtained. Weights of the children were measured before the procedure and then the Child Information Form was completed through face-to-face interview method. The second researcher explained both scales as well as assessment of the pre- and post- procedure pain and fear to the children and their parents. Following the group assignment, the child and his/her parents were taken into room for intramuscular injection. Before the injection, the pain and fear scales were scored blindly by the children, their parents, and the second researcher at the same time. During the intramuscular injection, a particular attention was paid to administration of the injection to the ventrogluteal area by using a 22-gauge needle, containing $70 \%$ alcohol as antiseptic solution and keeping the parents with their children in all three groups. The same medicine (ceftriaxone $500 \mathrm{mg}$, im $50 \mathrm{mg} / \mathrm{kg}$ ) was administered to all the children using a $5-\mathrm{ml}$ injector. The intramuscular injection was applied to the left or right ventrogluteal area by laying the child on one side ${ }^{(23)}$. Before the injection, the injection site was cleaned with a piece of alcohol cotton and dried. The needle was inserted into the ventrogluteal area with a 90-degree angle. After administering the medicine, the nurse waited for 10 seconds, removed the injector from the same angle and at the same speed, and pressed a piece of dry cotton on the injection site ${ }^{(24)}$. In all groups, the same nurse (the third researcher/ author) made intramuscular injections in order to remove the administration differences. The nurse performing the injection was a specialist nurse having experiences of providing care to pediatric patients and performing intramuscular injections for more than fifteen years. Each child was injected only once. With these steps, the injection procedure was ensured to be the same and standardized for all groups.

Control group: In the hospital, pharmacological or non-pharmacological method is not routinely used for alleviating the pain and anxiety during intramuscular injections. Thus, no intervention was applied to this group.

ShotBlocker group: ShotBlocker device was placed on the injection site by contacting the protru- 
ding surface with the skin which was kept in the same position throughout the injection. The injection was applied through the opening at the middle of the tool.

Buzzy group: Buzzy was placed $5 \mathrm{~cm}$ above the injection site 60 seconds before the procedure. Cold application and vibration were applied throughout the procedure. Afterwards, the ice pack was wiped with $70 \%$ alcohol and then put back in the deep freezer to refreeze.

In every group, pain and fear scales were scored again blindly by the children, their parents, and the second researcher right after the injection. Then, the parents were allowed to fill out the Satisfaction Questionnaire using the face-to-face interview method.

\section{Data analysis}

SPSS 21 software package was used for the data analysis. While the difference between the groups was evaluated using the Kruskal-Wallis $\mathrm{H}$ test, intragroup comparisons were made using the Wilcoxon signed-rank test. While the correlation between the variables was tested with the Spearman's correlation analysis, the correlation between categorical variables was tested with the chi-square analysis. The interobserver agreement was evaluated with the ICC (Interclass Correlation) analysis. The value of $p<.05$ was accepted as statistically significant ${ }^{(19)}$.

\section{Ethical consideration}

An approval from the Ethics Committee of a university hospital in Turkey (IRB number 07.11.2018/139) as well as institutional permission were obtained.
Written informed consents of the parents and their children were also obtained. Also, the study was registered with the number: NCT03915704.

\section{RESULTS}

\section{Comparing demographic data of the groups}

Totally 90 children participated in the study. Fifteen girls and 15 boys were included in each group. The mean age of 90 children of the study population consisting of intervention and control groups was $9.30 \pm 1.50$ (min-max: 6-12 yrs) years, their average weight was $29.80 \pm 5.70 \mathrm{~kg}$ (min-max: 18-41 kg), and the average number of im injections administered within one year was 3.90 \pm 1.60 (minmax: 2-10). Any statistically significant difference was not found among the groups and all the groups had homogeneous descriptive characteristics (Table $1 ; p>0.05)$.

\section{Comparing pain scores of the groups}

Any statistically significant difference was not found for all the groups concerning pre-procedure pain scores reported by the children, their parents and the researcher (Table 2; $p>0.05$ ).

The post-procedure pain scores of the control group were higher than those of the intervention groups (Table 2; $\mathrm{p}=0.0001$ ). The lowest pain score was observed in the Buzzy group (Table 2; $\mathrm{p}=0.0001$ ).

A highly significant agreement was determined between the child-parent-researcher observers respectively in the control, ShotBlocker and Buzzy groups before (ICC $=0.978 ; 0.969 ; 0.952 ; p=0.0001)$ and after the procedure $($ ICC $=0.923 ; 0.921 ; 0.948 ; p=0.0001)$.

Table 1. Comparison of descriptive characteristics of children in the study groups $(\mathrm{N}=90)$.

\begin{tabular}{|c|c|c|c|c|c|c|c|c|c|c|}
\hline \multirow{4}{*}{$\begin{array}{l}\text { Characteristics } \\
\text { Age (year) }\end{array}$} & \multicolumn{6}{|c|}{ Groups } & & & & \\
\hline & \multicolumn{2}{|c|}{ Shotblocker $(n=30)$} & \multicolumn{2}{|c|}{ Buzzy $(n=30)$} & \multicolumn{2}{|c|}{ Control $(n=30)$} & \multicolumn{2}{|r|}{ Total } & & \\
\hline & $\mathbf{n}$ & $\mathrm{X} \pm \mathrm{SD}$ & $\mathbf{n}$ & $\mathrm{X} \pm \mathrm{SD}$ & $\mathbf{n}$ & $\mathrm{X} \pm \mathrm{SD}$ & $\mathbf{n}$ & $\mathrm{X} \pm \mathrm{SD}$ & \multicolumn{2}{|c|}{ Test Value* } \\
\hline & 30 & $9.40 \pm 1.20$ & 30 & $9.10 \pm 1.70$ & 30 & $9.30 \pm 1.50$ & 90 & $9.30 \pm 1.50$ & $h=0.637$ & $p=0.727$ \\
\hline Weight (kg) & 30 & $30.40 \pm 4.80$ & 30 & $28.70 \pm 6.80$ & 30 & $30.20 \pm 5.30$ & 90 & $29.80 \pm 5.70$ & $h=1.600$ & $p=0.445$ \\
\hline Number of IM injections/year & 30 & $4.0 \pm 1.40$ & 30 & $3.70 \pm 1.50$ & 30 & $4.10 \pm 1.80$ & 90 & $3.90 \pm 1.60$ & $h=1.570$ & $p=0.456$ \\
\hline
\end{tabular}

*Kruskal-Wallis Test SD=standard deviation. 
Table 2. Comparison of the pain scores of the children in the intervention and control groups in terms of procedure times ( $\mathrm{N}=90)$.

\begin{tabular}{|c|c|c|c|c|c|}
\hline \multirow[b]{2}{*}{ Times } & \multicolumn{3}{|c|}{ Groups } & \multirow[b]{2}{*}{ Test Value* } & \multirow[b]{2}{*}{ Post-hoc analysis** } \\
\hline & $\begin{array}{c}\text { Shotblocker }^{a} \\
(n=30) \\
X \pm S D\end{array}$ & $\begin{array}{c}\text { Buzzy }^{b} \\
(n=30) \\
X \pm S D\end{array}$ & $\begin{array}{c}\text { Control } \\
(n=30) \\
X \pm S D\end{array}$ & & \\
\hline \multicolumn{6}{|c|}{ Before the procedure } \\
\hline Child & $0.13 \pm 0.35$ & $0.17 \pm 0.46$ & $0.20 \pm 0.48$ & $\begin{array}{l}h=0.198 \\
p=0.906\end{array}$ & \\
\hline Parent & $0.13 \pm 0.35$ & $0.10 \pm 0.31$ & $0.17 \pm 0.38$ & $\begin{array}{l}h=0.571 \\
p=0.752\end{array}$ & \\
\hline Researcher & $0.17 \pm 0.38$ & $0.13 \pm 0.43$ & $0.17 \pm 0.38$ & $\begin{array}{l}h=0.597 \\
p=0.742\end{array}$ & \\
\hline \multicolumn{6}{|c|}{ After the procedure } \\
\hline Child & $1.23 \pm 0.68$ & $0.23 \pm 0.50$ & $3.00 \pm 0.91$ & $\begin{array}{l}h=66.01 \\
p=0.0001\end{array}$ & $\begin{array}{l}c>a \\
c>b \\
a>b\end{array}$ \\
\hline Parent & $1.20 \pm 0.66$ & $0.20 \pm 0.48$ & $3.00 \pm 0.87$ & $\begin{array}{c}h=67.6 \\
p=0.0001\end{array}$ & $\begin{array}{l}c>a \\
c>b \\
a>b\end{array}$ \\
\hline Researcher & $1.27 \pm 0.64$ & $0.20 \pm 0.48$ & $2.97 \pm 0.81$ & $\begin{array}{c}h=69.1 \\
p=0.0001\end{array}$ & $\begin{array}{l}c>a \\
c>b \\
a>b\end{array}$ \\
\hline
\end{tabular}

*Kruskal-Wallis Test, **Wilcoxon Test

Table 3. Comparison of the fear scores of the children in the intervention and control groups in terms of procedure times ( $\mathrm{N}=90)$.

\begin{tabular}{|c|c|c|c|c|c|}
\hline \multirow[b]{2}{*}{ Procedure Times } & \multicolumn{3}{|c|}{ Groups } & \multirow[b]{2}{*}{ Test Value* } & \multirow[b]{2}{*}{ Post-hoc analysis** } \\
\hline & $\begin{array}{c}\text { Shotblocker } \\
\begin{array}{c}(n=30) \\
X \pm S D\end{array}\end{array}$ & $\begin{array}{c}\text { Buzzyb } \\
(n=30) \\
X \pm S D\end{array}$ & $\begin{array}{c}\text { Control }^{c} \\
(n=30) \\
X \pm S D\end{array}$ & & \\
\hline \multicolumn{6}{|c|}{ Before the procedure } \\
\hline Child & $2.47 \pm 0.82$ & $2.40 \pm 1.04$ & $2.33 \pm 0.96$ & $\begin{array}{l}h=0.823 \\
p=0.663\end{array}$ & \\
\hline Parent & $2.43 \pm 0.68$ & $2.37 \pm 1.03$ & $2.33 \pm 0.96$ & $\begin{array}{l}h=0.821 \\
p=0.664\end{array}$ & \\
\hline Researcher & $2.40 \pm 0.97$ & $2.40 \pm 1.10$ & $2.40 \pm 1.04$ & $\begin{array}{l}\mathrm{h}=0.236 \\
\mathrm{p}=0.889\end{array}$ & \\
\hline \multicolumn{6}{|c|}{ After the procedure } \\
\hline Child & $1.17 \pm 0.75$ & $0.20 \pm 0.41$ & $2.93 \pm 0.78$ & $\begin{array}{c}h=66.4 \\
p=0.0001\end{array}$ & $\begin{array}{l}c>a \\
c>b \\
a>b\end{array}$ \\
\hline Parent & $1.23 \pm 0.73$ & $0.27 \pm 0.45$ & $3.03 \pm 0.61$ & $\begin{array}{c}h=69.1 \\
p=0.0001\end{array}$ & $\begin{array}{l}c>a \\
c>b \\
a>b\end{array}$ \\
\hline Researcher & $1.20 \pm 0.76$ & $0.23 \pm 0.43$ & $3.03 \pm 0.81$ & $\begin{array}{c}h=66.1 \\
p=0.0001\end{array}$ & $\begin{array}{l}c>a \\
c>b \\
a>b\end{array}$ \\
\hline
\end{tabular}

*Kruskal-Wallis Test, **Wilcoxon Test

\section{Comparing fear scores of the groups}

Any statistically significant difference was not found among pre-procedure fear scores of all the groups (Table $3 ; p>0.05$ ).

The post-procedure fear scores of the children in the control group were higher than those of the intervention groups (Table $3 ; p=0.001$ ). The lowest fear score was found in the Buzzy group (Table 3; $\mathrm{p}=0.0001$ ).

There was a highly significant agreement between the child-parent-researcher observers respectively in the control, ShotBlocker, and Buzzy groups 
Table 4. Comparison of the satisfaction levels of the children in the intervention and control groups $(\mathrm{N}=90)$

\begin{tabular}{|c|c|c|c|c|c|c|c|c|}
\hline \multirow[b]{3}{*}{ Satisfaction items } & \multicolumn{6}{|c|}{ Groups } & & \\
\hline & \multicolumn{2}{|c|}{$\begin{array}{c}\text { Shotblocker } \\
(n=30)\end{array}$} & \multicolumn{2}{|c|}{$\begin{array}{c}\text { Buzzy } \\
(n=30)\end{array}$} & \multicolumn{2}{|c|}{$\begin{array}{c}\text { Control } \\
(n=30)\end{array}$} & \multicolumn{2}{|c|}{ Test Value* } \\
\hline & $\mathbf{n}$ & $\%$ & $\mathbf{n}$ & $\%$ & $\mathbf{n}$ & $\%$ & $x^{2}$ & $\mathbf{p}$ \\
\hline \multirow[t]{2}{*}{ Explanation before the injection } & Yes 30 & 100.0 & 30 & 100.0 & 28 & 93.3 & - & 0.333 \\
\hline & No 0 & 0.0 & 0 & 0.0 & 2 & 6.7 & & \\
\hline \multirow[t]{2}{*}{ Child was calm during the injection. } & Yes 20 & 66.7 & 30 & 100.0 & 4 & 13.3 & 59.1 & 0.0001 \\
\hline & No 10 & 33.3 & 0 & 0.0 & 26 & 86.7 & & \\
\hline \multirow[t]{2}{*}{ Method of reducing pain } & Yes 30 & 100.0 & 30 & 100.0 & 11 & 36.7 & 53.3 & 0.0001 \\
\hline & No 0 & 0.0 & 0 & 0.0 & 19 & 63.3 & & \\
\hline \multirow[t]{2}{*}{ Expecting the same method following injections } & Yes 26 & 86.7 & 30 & 100.0 & 7 & 23.3 & 53.7 & 0.0001 \\
\hline & No 4 & 13.3 & 0 & 0.0 & 23 & 76.7 & & \\
\hline \multirow[t]{2}{*}{ Advising the method to other parents } & Yes 25 & 83.3 & 30 & 100.0 & 1 & 3.3 & 83.1 & 0.0001 \\
\hline & No 5 & 16.7 & 0 & 0.0 & 29 & 96.7 & & \\
\hline
\end{tabular}

*Chi-square test

before the procedure $(I C C=0.962 ; 0.893 ; 0.955$; $\mathrm{p}=0.0001)$ and after the procedure $(\mathrm{ICC}=0.882$; $0.912 ; 0.931 ; p=0.0001)$.

\section{Comparing satisfaction levels of the groups}

The parents' satisfaction with the pre-procedure explanation did not show any statistically significant difference ( $p>0.05)$. On the other hand, among other parental satisfaction items, the lowest satisfaction was obtained in the control group, and the highest satisfaction was observed in the Buzzy group (Table 4; $p=0.0001$ ).

\section{DISCUSSION}

Intramuscular injections are invasive interventions causing pain and fear in children ${ }^{(3)}$. Thus, it is recommended for nurses to use effective nonpharmacological methods alleviating pain and fear during intramuscular injection ${ }^{(10)}$. Reducing pain and fear during intramuscular injections directly affects child and parent's satisfaction ${ }^{(3)}$. In this study, the effectiveness of ShotBlocker and Buzzy methods was compared as regards to reducing pain and fear felt by children during intramuscular injection, as well as parental satisfaction. The groups had homogeneously distributed variables influencing the children's pain and fear scores (Table $1 ; p>0.05$ ). Any statistically significant difference was not found between the pre-injection pain and fear scores of the groups (Tables 2-3; $p>0.05$ ). In addition, similar average weights of the children in the study groups $(p=0.445)$ revealed that the dose of medication administered showed no difference between the groups.

In the current study, the ShotBlocker and Buzzy groups had lower post-procedure pain scores than the control group and those in the Buzzy group had the lowest pain score (Table 2). Various studies have reported that ShotBlocker reduces pain experienced by children due to intramuscular injection ${ }^{(6,8)}$. In the study, the ShotBlocker group experienced less pain after the injection than the control group, which was associated with the effect of the gate control theory.

The literature reports that application of the Buzzy method which includes the combined use of vibration and external cold application has an effect on relieving pain in children during venous blood sampling ${ }^{(1,9-11)}$, insertion of intravenous catheter ${ }^{(12,13)}$ and vaccination ${ }^{(3,14)}$. In addition, studies comparing the effectiveness of the Buzzy method in children during intramuscular injection are limited with vaccination ${ }^{(3,14)}$. This study, unlike other studies, evaluated the effectiveness of the Buzzy method in children receiving antibiotic treatment via intramuscular injection. Baxter et al. ${ }^{(25)}$ stated that the Buzzy method reduced pain in children during invasive procedures using three non-pharmacological mechanisms 
as gate control theory ${ }^{(5)}$; descending noxious inhibitory control (26) and distraction. In the current study, lower pain scores were observed in the Buzzy group, which was associated with the combination of these three mechanisms.

In the present study, the children in three groups had moderate level of fear before the injection. The post-procedure fear scores of the control group were higher than the intervention groups and the lowest fear score was found in the Buzzy group (Table 3). In the literature, some studies have supported that these two methods reduce anxiety in children during invasive procedures ${ }^{(1,12)}$. Based on the gate control theory, the gate is opened by anxiety and fear so that the pain perception increases (27). For this reason, children with higher fear levels may have a higher pain response ${ }^{(28)}$.

Satisfaction level is a significant parameter used for the assessment of the quality of service ${ }^{(29)}$. The study by Redfern et al. ${ }^{(3)}$ revealed no significant difference between the parental satisfaction levels of control and Buzzy groups; whereas, the studies conducted with adults showed that the application of the Buzzy method increased satisfaction level in individuals ${ }^{(29,30)}$. In the study, the highest parental satisfaction was determined in the Buzzy group (Table 4). This result was associated with the fact that postprocedural pain and fear scores of the children were lower in the Buzzy group compared to the other groups.

\section{Limitations}

The first limitation of the present study is that it was not conducted as a double-blind trial since the researchers knew the group which the children were assigned to. Pain and fear scores were rated by the children, their parents, and a researcher to reduce potential researcher bias. Second limitation is that any non-pharmacological method was not used to relieve pain in the control group. Since these methods are not routinely administered in our unit, routine intramuscular injection procedures were performed for children in the control group.

\section{CONCLUSIONS}

Buzzy method was more effective in alleviating pain and fear of children and increasing satisfaction of their parents when compared to ShotBlocker method. Both ShotBlocker and Buzzy methods reduced pain and fear of children and increased satisfaction of their parents. Therefore, nurses are suggested to prefer primarily Buzzy method and then ShotBlocker method during their intramuscular injections. The use of Buzzy and ShotBlocker methods would contribute to the contemporary care of children during intramuscular injections in Turkey.

Ethics Committee Approval: An ethics committee approval and an institutional approval were obtained from the Ethics Committee of a university hospital in Turkey (IRB number 07.11.2018/139).

Conflict of Interest: The authors declare no conflicts of interest.

Funding: The authors received no financial support for the research, authorship, and/or publication of this article.

Informed Consent: Written informed consents of the parents and their children were obtained.

\section{REFERENCES}

1. Bergomi P, Scudeller L, Pintaldi S, Dal Molin A. Efficacy of non-pharmacological methods of pain management in children undergoing venipuncture in a pediatric outpatient clinic: a randomized controlled trial of audiovisual distraction and external cold and vibration. J Pediatr Nurs. 2018;42:e66e72.

https://doi.org/10.1016/j.pedn.2018.04.011

2. McMurtry CM, Noel M, Chambers CT, McGrath PJ. Children's fear during procedural pain: preliminary investigation of the Children's Fear Scale. Health Psychol. 2011;30(6):780-8. https://doi.org/10.1037/a0024817

3. Redfern RE, Chen JT, Sibrel S. Effects of thermomechanical stimulation during vaccination on anxiety, pain, and satisfaction in pediatric patients: a randomized controlled trial. J Pediatr Nurs. 2018;38:1-7.

https://doi.org/10.1016/j.pedn.2017.09.009

4. Taddio A, Appleton M, Bortolussi R, Chambers C, Dubey V, Halperin S, et al. Reducing the pain of childhood vaccination: an evidence-based clinical practice guideline. CMAJ. 2010;182(18):1989-95.

https://doi.org/10.1503/cmaj.092048

5. Melzack R, Wall PD. Pain mechanisms: a new theory. Science. 1965;150(699):971-9.

https://doi.org/10.1126/science.150.3699.971 
6. Guevarra AD. Efficacy of ShotBlocker in reducing pain associated with intramuscular injections in pre-school children. 2005. Retrieved from: https://www.bionix.com/healthathome/articles/efficacy-of-ShotBlocker-ma-abigail-dguevarra$\mathrm{md} / 12.04 .2019$.

7. Cobb JE, Cohen LL. A randomized controlled trial of the ShotBlocker for children's immunization distress. Clin J Pain. 2009;25(9):790-6. https://doi.org/10.1097/AJP.0b013e3181af1324

8. Drago LA, Singh SB, Douglas-Bright A, Yiadom AY, Baumann BM. Efficacy of ShotBlocker in reducing pediatric pain associated with intramuscular injections. Am J Emerg Med. 2009;27(5):536-43. https://doi.org/10.1016/j.ajem.2008.04.011

9. Baxter AL, Cohen LL, McElvery HL, Lawson ML, von Baeyer $\mathrm{CL}$. An integration of vibration and cold relieves venipuncture pain in a pediatric emergency department. Pediatr Emerg Care. 2011;27(12):1151-6. https://doi.org/10.1097/PEC.0b013e318237ace4

10. Inal S, Kelleci M. The effect of external thermomechanical stimulation and distraction on reducing pain experienced by children during blood drawing. Pediatr Emerg Care. 2020;36(2):66-9. https://doi.org/10.1097/PEC.0000000000001264

11. Gerçeker GÖ, Binay Ş, Bilsin E, Kahraman A, Yılmaz HB. Effects of virtual reality and external cold vibration on pain in 7 to 12 -year-old children during phlebotomy: a randomized controlled trial. J Perianesth Nurs. 2018;33(6):981-9. https://doi.org/10.1016/j.jopan.2017.12.010

12. Canbulat N, Ayhan F, İnal S. Effectiveness of external cold and vibration for procedural pain relief during peripheral intravenous cannulation in pediatric patients. Pain Manag Nurs. 2015;16(1):33-9. https://doi.org/10.1016/j.pmn.2014.03.003

13. Moadad N, Kozman K, Shahine R, Ohanian S, Badr LK. Distraction using the Buzzy for children during an IV insertion. J Pediatr Nurs. 2016;31(1):64-72. https://doi.org/10.1016/j.pedn.2015.07.010

14. Canbulat Şahiner N, Inal S, Akbay AS. The effect of combined stimulation of external cold and vibration during immunization on pain and anxiety levels in children. J Perianesth Nurs. 2015;30(3):228-35. https://doi.org/10.1016/j.jopan.2014.05.011

15. Canbulat Şahiner N, Sonay Türkmen A, Açıkgöz A, Şimşek E, Kirel B. Effectiveness of two different methods during insulin injection in children with type 1 diabetes: buzzy and shotblocker. Worldviews Evid Based Nurs. 2018;15(6):464-70. https://doi.org/10.1111/wvn.12325

16. Dougal RL, Anderson JH, Reavy K, Shirazi CC. Family presence during resuscitation and/or invasive procedures in the emergency department: one size does not fit. J Emerg Nurs. 2011;37(2):152-7. https://doi.org/10.1016/j.jen.2010.02.016

17. Paul SR, Wilkinson R, Routley C. Management of respiratory tract infections in children. Nursing: Research and Review. 2014;4:135-48.

https://doi.org/10.2147/NRR.S43033

18. Maria Pacifici G, Marchini G. Clinical pharmacology of ceftriaxone in neonates and infants: Effects and pharmacokinetics. Int J Pediatr. 2017;5(9):5751-77.

19. Şencan H. Sosyal ve Davranışsal Ölçümlerde Güvenilirlik ve Geçerlilik. Seçkin Yayınevi; 2005.

20. Bartley EJ, Fillingim RB. Sex differences in pain: a brief review of clinical and experimental findings. $\mathrm{Br} J$ Anaesth. 2013;111(1):52-8. https://doi.org/10.1093/bja/aet127

21. Wong DL, Hockenberry MJ. Wong's Nursing Care of Infants and Children. St. Louis:Mosby; 2003. p. 1-440.

22. Tomlinson D, von Baeyer CL, Stinson JN, Sung L. A systematic review of faces scales for the self-report of pain intensity in children. Pediatrics. 2010;126(5):11168-98. https://doi.org/10.1542/peds.2010-1609

23. Güneş ÜY, Ceylan B, Bayındır P. Is the ventrogluteal site suitable for intramuscular injections in children under the age of three? J Adv Nurs. 2016;72(1):127-34. https://doi.org/10.1111/jan.12813

24. Bindler RC, Ball JW. Clinical Skills Manual for Principles of Pediatric Nursing Caring for Children. 5th ed. United States: Pearson Education; 2011.

25. Baxter AL, Leong T, Matthew B. External thermomechanical stimulation versus vapocoolant for adult venipuncture pain: pilot data on a novel device. Clin J Pain. 2009;25(8):705-10. https://doi.org/10.1097/AJP.0b013e3181af1236

26. Nahra H, Plaghki L. Innocuous skin cooling modulates perception and neurophysiological correlates of brief $\mathrm{CO}_{2}$ laser stimuli in humans. Eur J Pain. 2005;9(5):521-30. https://doi.org/10.1016/j.ejpain.2004.11.007

27. Sparks L. Taking the "ouch" out of injections for children. Using distraction to decrease pain. MCN Am J Matern Child Nurs. 2001;26(2):72-8. https://doi.org/10.1097/00005721-200103000-00005

28. Twycross A. Pain: a bio-psycho-social phenomenon- nondrug methods of pain relief. In: Twycross A, Dowden SJ, Bruce E, editor. Managing Pain in Children. United Kingdom: Blackwell Publishing; 2009. p. 29-38. https://doi.org/10.1002/9781444322743.ch3

29. Yılmaz D, Heper Y, Gözler L. Effect of the use of Buzzy during phlebotomy on pain and individual satisfaction in blood donors. Pain Manag Nurs. 2017;18(4):260-7. https://doi.org/10.1016/j.pmn.2017.03.005

30. Şahin M, Eşer I. Effect of the Buzzy application on pain and injection satisfaction in adult patients receiving intramuscular injections. Pain Manag Nurs. 2018;19(6):645-51. https://doi.org/10.1016/j.pmn.2018.07.009 